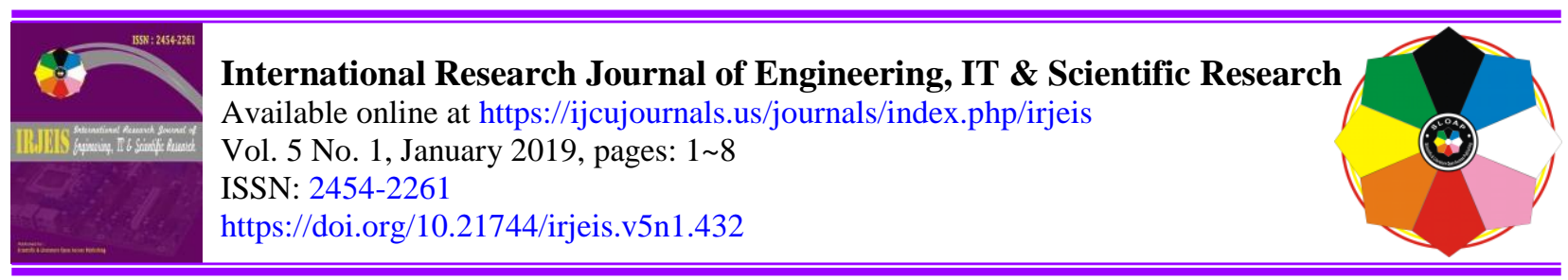

\title{
Design of Zeolite Filter for Ammonium Removal in Wastewater
}

\author{
Luis Armando Suarez Hidalgo ${ }^{\text {a }}$ \\ Maria Shirlendy Guerrero Alcivar ${ }^{b}$ \\ Ramona Panchana de Calderero ${ }^{\mathrm{c}}$ \\ Jorge Lider Macias Ramos ${ }^{\mathrm{d}}$
}

Article history:

Received: 9 July 2018

Accepted: 30 November 2018

Published: 5 December 2018

\section{Keywords:}

pollutant discharges;

river;

water pollution;

zeolite filter;

zeolite;

\begin{abstract}
The search for alternative methods that are less expensive and more friendly to the environment is a priority task for the world of science, and simple solutions based on the use of indigenous resources come into play. Natural zeolite is one of the materials that offer the possibility of reducing wastewater pollution, being an abundant mineral in some poor developing nations, hence its use is a cost-friendly and environmentally friendly alternative. In the work, the mineralogical characteristics of the zeolite are analyzed, making it a formidable filtering material of contaminated waters and the existence of deposits of this mineral in the province of Guayas, Ecuador. An environmental characterization of the Portoviejo river is carried out, where the pollution that is occurring is revealed through the existence of more than 300 effluents that discharge the wastewater into the river. The calculations are shown for the design of the zeolite filter that is proposed for the reduction of the contamination of the wastewater that is discharged to the Portoviejo river at the height of the Velazco Ibarra bridge of the city of the same name and a technical scheme of the filtering device based on the use of zeolite. Finally, the conclusions are exposed, where the feasibility of introducing the zeolite filter into the effluent mentioned above is analyzed and its experimental introduction is recommended in 10 of the main effluents that exist in the limits of the city of Portoviejo.
\end{abstract}

2454-2261 ${ }^{\odot}$ Copyright 2019. The Author. Published by SLOAP. This is an open-access article under the CC-BY-SA license (https://creativecommons.org/licenses/by/4.0/) All rights reserved.

\section{Author correspondence:}

Luis Armando Suarez Hidalgo,

Faculty of Mathematical, Physical, and Chemical Sciences of the Universidad Técnica de Manabí, Civil

Engineering Career.

Email address: armandosuarezhidalgo@gmail.com

a Universidad Tecnica de Manabi, Portoviejo, Manabi, Ecuador

${ }^{\mathrm{b}}$ Universidad Tecnica de Manabi, Portoviejo, Manabi, Ecuador

${ }^{\mathrm{c}}$ Universidad Tecnica de Manabi, Portoviejo, Manabi, Ecuador

${ }^{\mathrm{d}}$ Universidad Tecnica de Manabi, Portoviejo, Manabi, Ecuador 


\section{Introduction}

It can be said that environmental pollution as we know it, is inherent to traditional models of development. The more developed a country is, society tends to consume more and pollution occurs as a diametrical result of the intensive use of natural resources and the extensive generation of residuals of all kinds. To this, we must add the little effort that the main polluters dedicate to settle their environmental debt with society. Decontamination methods and mechanisms are expensive and in some cases generate other types of pollution The contamination of water sources is a serious problem facing humanity today (Castellón et al., 2015). Natural resources are insufficient if current policies of development and consumption continue (Caballero et al., 2017). This situation has caused collateral problems such as over-exploitation of aquifers, so it is necessary to take feasible measures, from all points of view, to reduce the problems of water supply. Pinoargote et al., (2018), one of the alternatives that can be applied to reduce this problem is the treatment of wastewater by methods that allow water to be reused by adding established quality parameters (Guerrero, 2017).

It has been found that, by appropriately adding natural zeolites in their various cationic modifications in the filtration systems, quite remarkable levels of water purification can be achieved, and not only the removal of phosphates, sulfates, and chlorides can be achieved; but also, the elimination of heavy metals such as lead, arsenic, nickel, copper, etc. (Guerrero, 2017).

The composition of wastewater is very variable due to several factors, among which are: the average water consumption per inhabitant per day, which affects its concentration and the dietary habits of the population, which characterizes its chemical composition. Wastewater is collected in the sewage system and then subjected to a treatment. When a sewage system is designed to collect wastewater and rainwater together it is known as combined. Domestic wastewater is constituted in a high percentage (by weight) by water, close to $99.9 \%$ and only $0.1 \%$ of suspended, colloidal and dissolved solids (Ramírez, 2001).

The chemical contamination of water can be eliminated by different processes, among which desorption and ion exchange stands out. The application of the second method is expensive if commercial resins are used, however, it can be feasibly economical if these are replaced by cheaper materials such as natural zeolites. The treatment of water by the ion exchange process leads to the need to establish the most suitable operating conditions ( $\mathrm{pH}$, type of resin, contact time, etc.) for the removal of the key contaminant. The objective of the work is aimed at developing the design of a filter to reduce the pollution of wastewater discharged into the Portoviejo River by an effluent located on the Velazco Ibarra bridge in the city of the same name.

\section{Materials and Methods}

Field research was used since the work was carried out in the place where the problems are generated, say in the wastewater effluent located in the Velazco Ibarra bridge in the city of Portoviejo; of experimental type because it was necessary to carry out laboratory tests to determine the physical-chemical and bacteriological characteristics of the wastewater that is being discharged from the Portoviejo river; bibliographic because a wide search of bibliography was developed in internet and libraries, being able to consult a total of 47 bibliographic documents, of which 12 were referred and; descriptive because it has been able to describe and evaluate the pollution that the river is being subjected to, its causes, consequences and it was possible to expose the design of a filtering device to reduce the environmental pollution of the wastewater that is being discharged to the river (Recio, 2018).

\section{Results and Discussions}

\subsection{Zeolite as a wastewater decontaminating agent}

Zeolites are hydrated aluminosilicate minerals with a cage-like structure that harbors large areas both externally and internally. They have a structure of negative charge due to the isomorphic substitution of cations in the mineral. Therefore, they have a strong affinity for cations and only a small affinity for anions or organic molecules. Clinoptilolite is the most abundant natural zeolite and, therefore, is a very economical material. This type of mineral is very efficient for the removal of ammoniacal nitrogen present in wastewater (Guerrero, 2017). 
Since 1954, natural zeolites have been the object of a large number of researchers in the scientific-technological world for their exceptional and diverse applications and in this short space of time, more than 20,000 articles and 2,000 patents have been published that refer to its synthesis, properties, structures, and applications (Loor \& Murillo, 2017).

Until the mid-90s in Ecuador, there was no knowledge of the existence of potential deposits of zeolites and even less of their properties and applications in the industry. It was in these years when a mission of Cuban experts traveled the Ecuadorian coast and found indications of zeolitic materials, which appear mainly in the Cayo Formation, near Guayaquil (Guerrero, 2017; Loor, 2017).

The known indications were not investigated in greater depth. At the end of the 90s, one of the Cuban experts proposed to the executives of the Polytechnic School of the Litoral (ESPOL) a research project on the applications of natural zeolites of the Cayo Formation; The authorities of this study center supported these ideas and the project began to develop with very satisfactory results, which set the tone for future research in this field (Garcés \& Morante, 2017).

Subsequent to the aforementioned, the Center for Scientific and Technological Research (CICYT) of ESPOL supported the conduct of other investigations regarding zeolites. An international seminar was held, sponsored by Network XIII - C (Rocks and Industrial Minerals) of the CYTED Program, to give knowledge of the characteristics and properties of natural zeolites. This seminar took place in Guayaquil in April 2001 with the participation of experts from Cuba, Ecuador, Chile, El Salvador and Brazil (Morante, 2004).

Finally, in 2002, the research project entitled: "Geometry Project of Natural Zeolites in the Gustavo Galindo Polytechnic Campus" was approved. The project was designed with the aim of estimating the zeolitic potential of the area and recognizing the most favorable places for exploration (Morante, 2004).

Zeolites remove ammonia ions in solution by ion exchange, which is not possible with sand or diatomaceous earth. Zeolites have a wide range of local applications: in agriculture (as fertilizer in banana and coffee plantations), in animal husbandry (animal nutrition and deodorization of barns) and in aquaculture (extraction of ammonium from shrimp culture pools) (Morante et al., 2011).

Due to its extremely porous structure, the natural zeolite is much denser than sand and therefore needs less amount of zeolite to obtain the same effect. Given the capacity of ion exchange, zeolite has an added advantage that is the elimination of contaminants that other filtering substances cannot eliminate. Among the advantages are that sand filters remove particles up to 40 microns in size. Zeolite filters remove particles up to 4 microns that are equivalent to the filtering capacity of diatomaceous earth. Zeolites have a high durability and their useful life is much longer than that of sand (Zurita, 2008).

\subsection{Discharges of wastewater to the Portoviejo River}

Groundwater has been used for home, livestock, and irrigation since the earliest times. The natural chemical quality of the groundwater is generally good, but the high concentrations of certain components that filter to the aquifer sources due to environmental contamination can cause serious problems. Ammonia in solution reacts with chlorine to form chloramine $\left(\mathrm{NH}_{2} \mathrm{Cl}\right)$, which causes eye irritation and odors in pool water (Recio, 2018).

Currently, the Portoviejo river is the main source of water for more than seven hundred thousand inhabitants of the cities of Portoviejo, Manta, Jipijapa, Rocafuerte, Montecristi, Santa Ana, Jaramijó, May 24 and part of Sucre. Around 300,000 people live on its banks, where there is an intense agricultural activity that has life in its valley, although its added value is very low. In rainy winters it causes floods in the city and in the countryside. It drains its waters in an area of $2108.29 \mathrm{Km}^{2}$. The basin consists of 3 sub-basins and 23 micro-basins, ranging from $338 \mathrm{~km} 2$ to $3.5 \mathrm{~km} 2$. However, the contamination of its waters is a problem that has behaved progressively as the population has grown, which is currently a real concern for the authorities and society in general (Caballero et al., 2017).

In the city of Portoviejo capital of the province of Manabí wastewater is an inevitable product of human activity. Pollution sources originate in the runoff of cropland affected by the use of fertilizers, as well as industrial and domestic waste. It can be argued that for several years they have been taking samples of the Portoviejo river water that are taken to the laboratory located in the Poza Honda dam for the respective analysis of them, determining the parameters of $\mathrm{PH}, \mathrm{BOD}, \mathrm{COD}$, dissolved solids, total solids among others, which can provide data to know the water quality index. The results obtained have shown that in some cases water pollution is high.

The environmental situation of the waters of the Portoviejo River is a problem that directly threatens the health of people residing on the banks of the river. The authorities of the Provincial Government of the Province of Manabi,

Hidalgo, L. A. S., Alcivar, M. S. G., Calderero, R. P. de, \& Ramos, J. L. M. (2018). Design of zeolite filter for ammonium removal in wastewater. International Research Journal of Engineering, IT and Scientific Research, 5(1), 
have devoted enormous efforts to correct the problems of pollution that presents the waters of this river, resulting in very expensive the use of artificial resins, so the use of zeolite can be a solution relevant to that problem.

Taking into account the high selectivity of the zeolite, cation exchange has been considered as a technological alternative for reducing the pollution of the wastewater discharged into the Portoviejo river. One of the problems is given by the presence of excess nitrogen in the environment, which has caused serious distortions of the natural cycle of nutrients between living organisms and the compartment of soil, water, and air. Ammoniacal nitrogen is soluble in water, which means that it can contaminate underground sources by infiltration mechanisms (Caballero et al., 2017).

The design and introduction of a filter based on zeolite and sand can contribute significantly to the reduction of environmental pollution of the wastewater discharged into the Portoviejo river at the height of the Velazco Ibarra bridge, especially the ammonium content that It has this effluent. In 2017, an experimental research project was carried out by students of the Technical University of Manabí, related to the use of zeolite to reduce the environmental pollution of the wastewater discharged into the Portoviejo river, where it was possible to verify following (Loor et al., 2017):

a) With the application of the filtering of wastewater from the effluents that go to the Portoviejo river, through the use of a particulate zeolite filter, environmental pollution in these waters was reduced.

b) The physical-chemical characterization of the water was carried out in five effluents of the Portoviejo river: Velazco Ibarra bridge; Puente de la Calle Miguel H Alcívar; effluent in front of the Portoviejo wastewater treatment plant; jump bridge and; Picoazá bridge, being able to verify in all cases the presence of an important environmental contamination that threatens the life of the river, especially with high levels of ammoniacal content.

c) During the development of the investigation the evaluation of the possibilities of the use of zeolite for the reduction of the environmental contamination of the wastewater of the city of Portoviejo was carried out, being able to verify through the laboratory analyzes that after applying the filtrate With zeolite, it is possible to reduce the environmental pollution of wastewater significantly.

d) The work allowed the assessment of the economic, social and environmental impact on the implementation of the model for the use of zeolite in the improvement of water quality in the city of Portoviejo.

e) It was verified that a water treatment plant for a city like Portoviejo that does not yet exceed half a million inhabitants, costs at least 5 million dollars. Wastewater treatment systems that use resins and other products are expensive to maintain. A zeolite filter for an effluent can cost between $\$ 3,000$ and $\$ 5,000$ depending on its size. The construction of 300 filtering systems based on zeolite, which would be giving an immediate response to the wastewater discharges that the Portoviejo River currently presents, would be costing between 900,000.00 USD and 1500 000.00 USD, representing an important saving in the economic matter for the territory.

\subsection{Design of the zeolite filter for the sewage effluent of the Velazco Ibarra bridge}

Subsection should be written without a bold type. The result and analysis are presented by present form. Please avoid too many paragraphs in this section. During the study, the side of the river in the sector of the Velazco Ibarra bridge was verified. Tables 1, 2 and 3 show the results of the calculation depending on the time of day.

Table 1

Flow calculation at 07:00 hours

\begin{tabular}{lllllll}
\hline $\begin{array}{l}\text { Day of } \\
\text { completion (day) }\end{array}$ & $\begin{array}{l}\text { Time made } \\
(\mathrm{h})\end{array}$ & $\begin{array}{l}\text { Time } \\
(\mathrm{s})\end{array}$ & $\begin{array}{l}\text { Volume } \\
(\mathrm{L})\end{array}$ & $\begin{array}{l}\mathrm{V} / \mathrm{T} \\
(\mathrm{L} / \mathrm{s})\end{array}$ & $\begin{array}{l}\text { Average } \\
(\mathrm{L} / \mathrm{s})\end{array}$ & $\begin{array}{l}\text { Average + 10\% } \\
(\mathrm{L} / \mathrm{s})\end{array}$ \\
\hline 1st day & $07: 00$ & $4 "$ & 20 & 5.00 & & \\
2nd day & $07: 00$ & $4.01 "$ & 20 & 4.99 & 5.21 & 5.72 \\
3rd day & $07: 00$ & $3.55 "$ & 20 & 5.63 & & \\
\hline
\end{tabular}


Table 2

Calculation of flow at 1:00 p.m.

\begin{tabular}{llllll}
\hline $\begin{array}{l}\text { Day of completion } \\
\text { (day) }\end{array}$ & $\begin{array}{l}\text { Time made } \\
(\mathrm{h})\end{array}$ & $\begin{array}{l}\text { Time } \\
(\mathrm{s})\end{array}$ & $\begin{array}{l}\text { Volume } \\
(\mathrm{L})\end{array}$ & $\begin{array}{l}\mathrm{V} / \mathrm{T} \\
(\mathrm{L} / \mathrm{s})\end{array}$ & $\begin{array}{l}\text { Average } \\
(\mathrm{L} / \mathrm{s})\end{array}$ \\
\hline 1st day & $13: 00$ & $5.52 "$ & 20 & 3.62 & \\
2nd day & $13: 00$ & $5.55 "$ & 20 & 3.60 & 3.61 \\
3rd day & $13: 00$ & $5.53 "$ & 20 & 3.62 & \\
\hline
\end{tabular}

Table 3

Calculation of the flow at 18:00 hours

\begin{tabular}{llllll}
\hline $\begin{array}{l}\text { Day of } \\
\text { completion } \\
\text { (day) }\end{array}$ & $\begin{array}{l}\text { Time carried out } \\
\text { (h) }\end{array}$ & $\begin{array}{l}\text { Time } \\
(\mathrm{s})\end{array}$ & $\begin{array}{l}\text { Volume } \\
(\mathrm{L})\end{array}$ & $\begin{array}{l}\mathrm{V} / \mathrm{T} \\
(\mathrm{L} / \mathrm{s})\end{array}$ & $\begin{array}{l}\text { Average } \\
(\mathrm{L} / \mathrm{s})\end{array}$ \\
\hline 1st day & $18: 00$ & $4.12 "$ & 20 & 4.85 & \\
2nd day & $18: 00$ & $4.10^{\prime \prime}$ & 20 & 4.88 & 4.85 \\
3rd day & $18: 00$ & $4.15 "$ & 20 & 4.82 & \\
\hline
\end{tabular}

Having as a result that 07:00 hours the highest flow is obtained, therefore, a safety factor of $10 \%$ is increased for the filter design, applied equation 1.

$$
\begin{aligned}
& Q=5.20+10 \%=5.72 \mathrm{l} / \mathrm{s} \\
& Q=5.72 \frac{l}{\mathrm{~s}} * \frac{1 \mathrm{~m}^{3}}{1000 \mathrm{l}} * \frac{3600 \mathrm{~s}}{1 \text { hora }}=20.59 \mathrm{~m}^{3} / \text { hora }
\end{aligned}
$$

For the calculation of the height of the zeolite in the filter was used equation 2.

$$
\begin{gathered}
\text { height of zeolite }=0.16+3.38(\Delta p)=0.16+3.38(0.70)=2.526 \mathrm{~m} \\
A=1.5 * 1.5=2.25 \mathrm{~m}^{2}
\end{gathered}
$$

For the calculation of the speed, the equation was used 3.

$V=\frac{Q}{A}=\frac{20.59^{m^{3}} / \text { hora }}{2.25 \mathrm{~m}^{2}}=9.15^{\mathrm{m}} /$ hora

Where:

$\Delta \mathrm{p} \rightarrow$ meter of the water column

$\mathrm{Q} \rightarrow$ flow rate

$\mathrm{V} \rightarrow$ speed

$\mathrm{A} \rightarrow$ area

$\mathrm{h} \rightarrow$ height

granulometry of zeolite $0.5-2.5 \mathrm{~mm}$

average diameter $1.2 \mathrm{~mm}$

Having a zeolite filter with an average diameter of $\mathrm{Dp}=1.2 \mathrm{~mm}$, an effective size of $\mathrm{TE}=0.9 \mathrm{~mm}$ and a uniformity coefficient $=1.5$, the operating speed in time of the highest filter performance for zeolite ranges from 3-9 $\mathrm{m} 3 / \mathrm{m} 2 *$ hour.

Figure 1 shows the design of the zeolite filter that is proposed to be applied to the effluent that discharges wastewater at the Velazco Ibarra bridge in the city of Portoviejo.

Hidalgo, L. A. S., Alcivar, M. S. G., Calderero, R. P. de, \& Ramos, J. L. M. (2018). Design of zeolite filter for ammonium removal in wastewater. International Research Journal of Engineering, IT and Scientific Research, 5(1), 


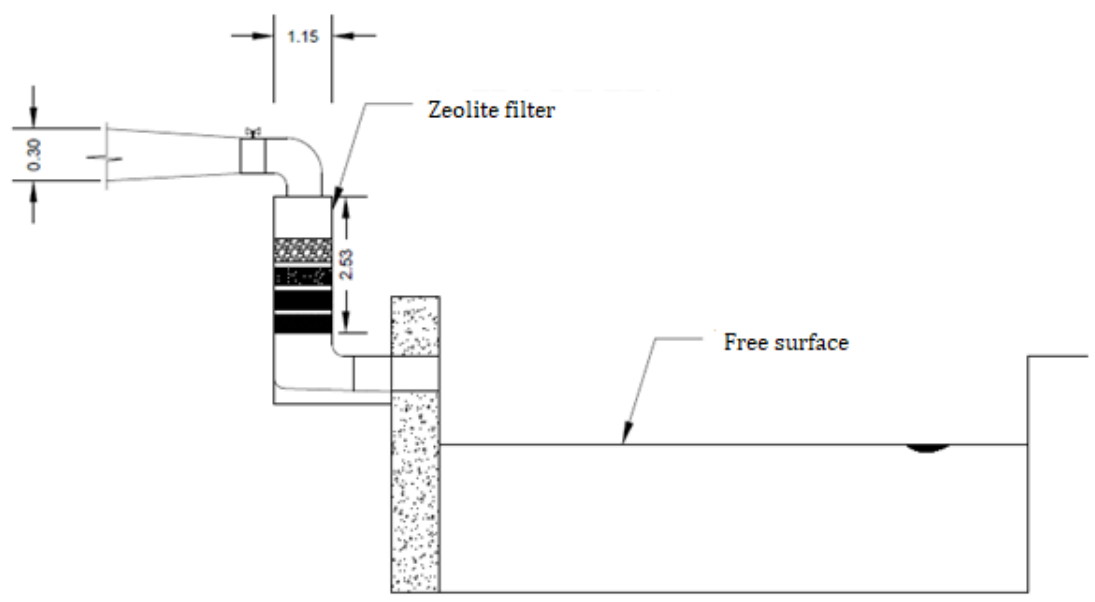

Figure 1. Zeolite filter that is proposed to apply

Source: Prepared by the authors based on data from (Loor et al., 2017) and (Guerrero, 2017)

\section{Conclusion}

The investigation allowed deepening the mineralogical characteristics of the zeolite and its properties as a filtering material to reduce the environmental pollution of Wastewater discharged into the Portoviejo river. A review was made of the environmental situation of the Portoviejo River and the effluents that are currently discharging wastewater into its bed.

The work allowed for the design of a filter based on the use of articulated zeolite, with the aim of reducing the environmental pollution of the water that is being discharged to the Portoviejo River in an effluent that is located at the Velazco Ibarra bridge. It was possible to analyze the feasibility related to the application of zeolite filters in about 300 effluents that currently discharge their wastewater to the Portoviejo river, proving that the application of the proposed filter is more economically viable and environmentally friendly, since its cost would be below in relation to the construction of a wastewater treatment plant and the environmental impact would be lower.

\section{Conflict of interest statement and funding sources}

The authors declared that they have no competing interest. The study was financed by the authors.

\section{Statement of authorship}

The authors have a responsibility for the conception and design of the study. The authors have approved the final article.

\section{Acknowledgments}

We would like to thank the reviewers for their consideration to review the present paper. Thank the editorial team for their valuable support, time and advice. 


\section{References}

Alcivar, M. S. G., Pérez, A. V., Gilert, B. I. C., \& Gámez, M. R. (2017). Zeolite in Wastewater Decontamination as a Local Development Solution. International Journal of Life Sciences (IJLS), 1(3), 1-13. https://doi.org/10.21744/ijls.v1i3.52

Castellón Gómez, J. J., Bernal Muñoz, R., \& Hernández Rodríguez, M. D. L. (2015). Calidad del agua para riego en la agricultura protegida en Tlaxcala. Ingeniería, 19(1).

Espejel Carbajal, I., \& Ramírez Flores, O. M. (2001). Las aguas residuales municipales como fuentes terrestres de contaminación de la zona marino-costera en la región de América Latina y El Caribe.

Garcés, D. (2013). Caracterización mineralógica del depósito de zeolitas naturales en el río Guaraguau (Isidro Ayora, provincia del Guayas) y su aplicación en la remoción de amonio en aguas residuales.

Giler, B., Gutiérrez, C., Mendoza, M., \& Pérez, A. (2017). Water Quality of the Poza Honda Dam and Other Water Points Down.International Research Journal of Engineering, IT \& Scientific Research, 3(3), 1-9. https://doi.org/10.21744/irjeis.v3i3.444

Loor Bravo, H. A., \& Meza Vélez, G. W. (2017). Estudio para la implementación de un molino analítico para el uso del laboratorio de bromatología para la facultad de ciencias veterinarias de la universidad técnica de manabí. extensión lodana (Bachelor's thesis).

Loor, A.M.V. and J.M.O. Murillo (2017). Evaluación de la remoción de amonio en aguas residuales, empleando zeolita particulada de diferentes diámetros. Trabajo de titulación previo a la obtención del título de Ingeniero. Facultad de Ciencias Matemática, Física y Química de la Universidad Técnica de Manabí.

Morante Carballo, F. E. (2004). Las zeolitas de la costa de Ecuador (Guayaquil): Geología, caracterización y aplicaciones(Doctoral dissertation, Minas).

Morante, F., Carrión, P., Garcés, D., \& Machiels, L. (2011). Desarrollo de las investigaciones en Zeolitas Naturales en el Ecuador.

Pinoargote, J. A. P., Alcivar, J. T. R., \& Viteri, C. G. V. (2018). Analysis and design of wastewater treatment. International Journal of Life Sciences, 2(3), 121-135. https://doi.org/10.29332/ijls.v2n3.221

Recio, F.J. (2018), Cloramina, el veneno que se oculta en las piscinas. El Mundo.

Zurita, J. (2008). Diseño de un sistema de filtración mediante zeolitas naturales para verificar la depuración del estero Salado del Guayaquil. Tesis de grado. Facultad de Ciencias Químicas. Escuela Superior Politécnica de Chimborazo. Riobamba. Ecuador.

Hidalgo, L. A. S., Alcivar, M. S. G., Calderero, R. P. de, \& Ramos, J. L. M. (2018). Design of zeolite filter for ammonium removal in wastewater. International Research Journal of Engineering, IT and Scientific Research, 5(1), 


\section{Biography of Authors}

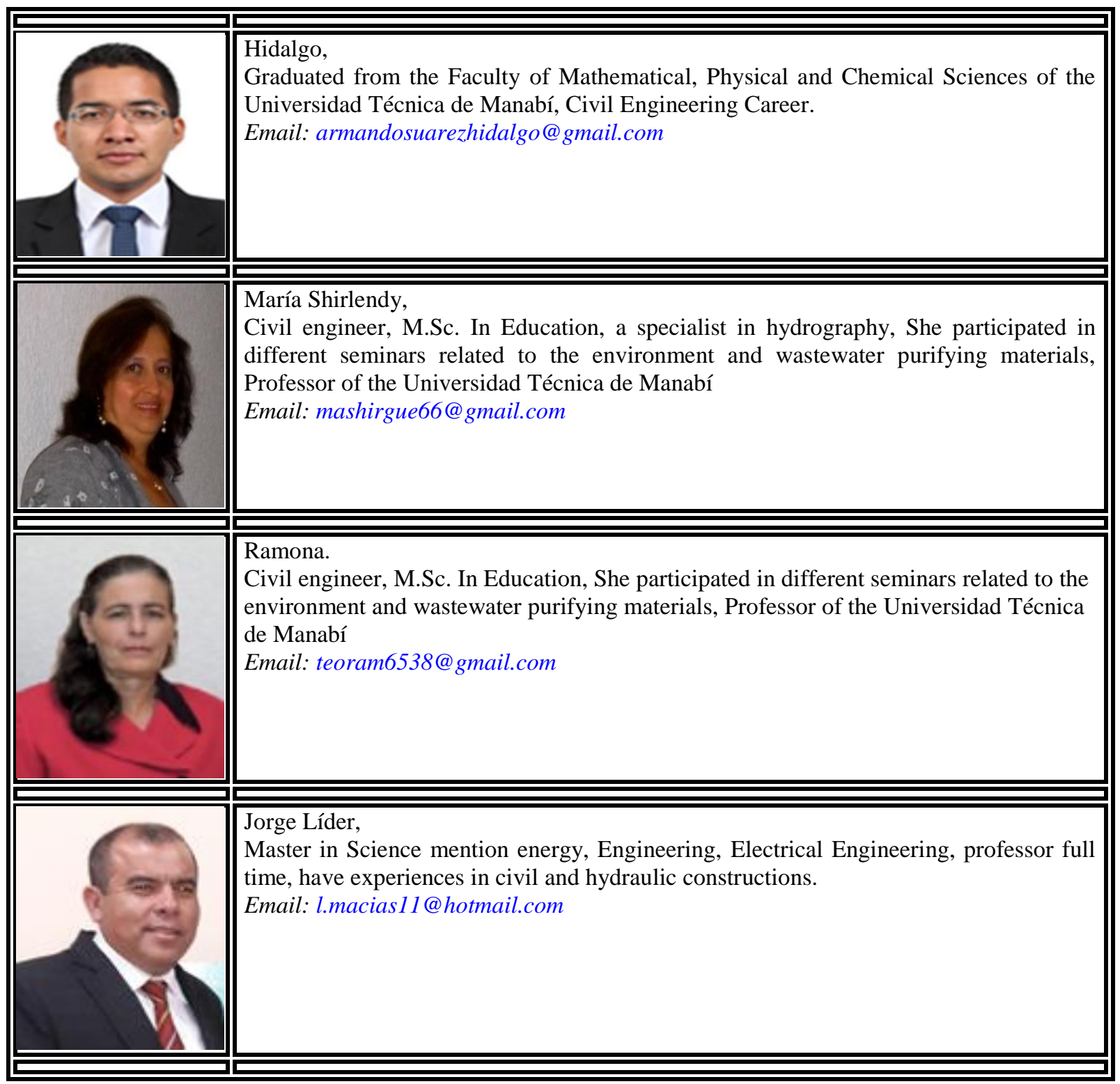

